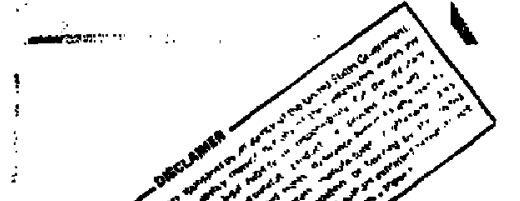

\title{
c. 1.
}

OPERATION OF THE PEP TRANSVERE-AEAY FEEDAAC,

SLAC-PUB-2690

PEP-NOTE-348

Februaty 1981

(A)

$\therefore \therefore+\ldots+15$ Stanford LIngar Accelerator Centwr

Stanford Untversity, stonford, Californio 94305

\section{Abatract}

I'he PEP Scorage Ring has been equipped whth a wide iasd board feedback syotera capable of damping the vartial and hortzontal motion of $21 x$ bunches. The gaclilaeton detection is done at a symetry poinc on the storage R1ng and feedback 1s applied at the locetim one orbital peilod later. The signal is oynchronously gated and the eyster apposes as tuelve indopendant feedbask loops, operat ing on the rwo coordisates of each of the $s i x$ bunches. Twa boam deflection eletcrodes are driven each by $\Omega$ low-Q puah-pull amplifier which is tuned at the 72nd hatmonle of the revolution frequarcy and suppresed-carrier modulation is genereted by a sequence of the deterced innch oscillations. The design parameters are reviewod as $m 11$ as the salient featurea of the haseware, and the impact of this systen on the machine operat ion is eveluated in the light of experimeptal reulte.

\section{Int foduction}

Meny cfrcular acceleratots and storago rings have used, Is the pasc, sose kind of beam feedback technique co provide danping or ant I-duping for sheir colvertent crangverse instab111tios. In some cases, feedtanck can be more then a diagnostic tool and becoues Indispansable to the proper opetation of the machine.?

While the exterta for selecting the loop gatind of cheae oytems are not very different between one and isocher, the hardwar design can iffer considerably cepestang on the number of bunches and the number of ades one vace to danf, and also it can differ almply because of tone particular inclination of the designers. There are rossibly chree arads where they can exarelase their ingenutty or thetr proferepce: the beam ancinlotion detect on clrcults, the informacion otorage and phasing olateac, the auplifiter chain and the beat istcker. For instence, the Refe, 2-5 deactibe, finong others, oyetems which heve bens conmissloned over the past five years and of inl quite variecy of approaches in the three above-ment $f$ ond t areas. Keepting with this rradition, we present heris the design for a vide band feedback systen treatiay two beans on a bunch by bunch bas18. We chose to use a gystem in which the banmdeflerting electrode 16 driven by $a$ radi af requency amplifier operating on a carrier et 9.8 milu; this trequepcy is tise 72nd harmonts of the beans' orbitsl trequency. Double-sideband, ouppressed-carrier modulation 15 used so the carrifer is in fact not ptesent in the electrode and there is no deflecting current wen the beans are not oset11 lacing coherent 1 . This schend results in low power digsipotion whes the be and are quict. The modulation prigram is fumished by a set of normalized oocillat $n^{n}$ l detectors and the unfiltered hunch position information is held unill the wext macline turs in an analog mepory.

\section{Sustem Dencriptien}

The defletting electrodes are alcuated at a polnt on the eircuference of the etorage fint equidietent betweon two interaction polnts, a location at which the six bunches at tise two PBp beans pass at equal intarvals of a ittle wore than one microsecond. The bandwidth of

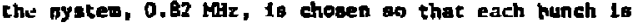
created nearly independently, or to put it another way. so that che normal node frequeacles of the enrenble of s1x bunches all fajl ufthin the passband of the aysien.

The damping rate tequired of the feedback dater-ines the loop gain. We destgned for a damplas eime of 700 microseconds at b been energy of $4 \mathrm{CeV}$ or equivalently 2.8 miIllseconds at $16 \mathrm{Gel}$. The maxiow current which tan be driven by the IInal amplifler iato the deflocting electride, ceterwines the wrinum aplitude of cohnerent bean motion which can be acted on by the syetex uthour saturifion. The PSP leadback system is designed to handle axplitudas up to 2 ntllimetera which produce eleetrode currents op to 20 apperes.

The vertical tand the hordzontal oysters are of courge Identical end each one contalns 6 Independent stgmal pathe, one for each bunch. These stemal paths are altern;tely enabled for 1.2 ve; this clme to appronimately p qual to three output-circult decay tive constant \%. Figure I dapiets one of these signal peths; some such as the multiplexer, the mudulator and the power arplifler are comon co the five other loops. The bem siguald ate obtained frow a pair of strip lines, wa pate for each bejo. then they reach the oupport building wert the proceasing circuite are installed, the pulses are bipolar itth peaks medsuring approntmately II volt per of of verige current par busach for the vertical pick-up electrode, and perhaps half as large for the horizontel pick-up electrode which is further away from the buat. The lim beveen the posiclve and the megative excurston of the palne 1 s of the order of $1.5 \mathrm{~ns}$, and the abount of codulation obererwed an the ereat of the pulse an a rewolt of besin odedilations in mearly 37 per allifepter fur the verclesl pick-up and halt this amount fur the horizantal plck-up. Each of thege signale is split chree tiwas in arder to be efmuleaneously applied to three doteetars.

The circult for the Momallzed Detector hes ben anslyzed elseuhere but wo roproduce on P1g. 2 V bloek diegres and ans. 3 a typech aet of thput-outpot murefores for one bunch. Together with the ptck-up electrode this detection syuten has a censitivity of

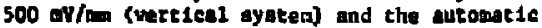
gain control circult can operate reliably with

Hork eupported by the Lephrtant of Enersy, contract bi-Ac03-76sFoosis. 


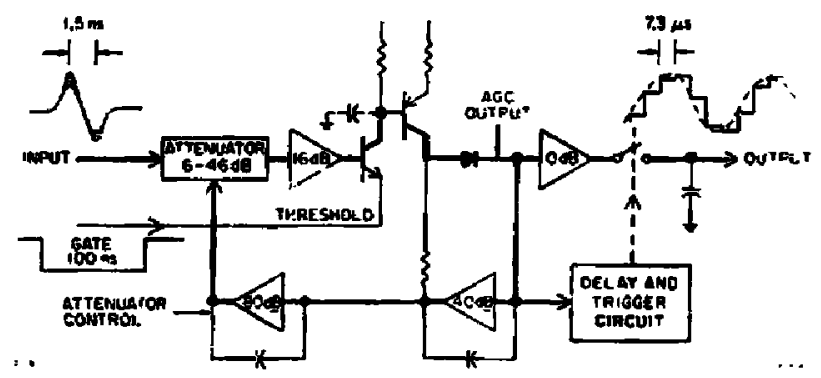

Fig. 2. Prineiple of the bean ogcillacton detection.

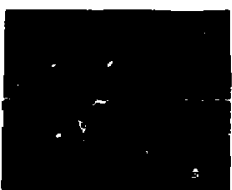

set

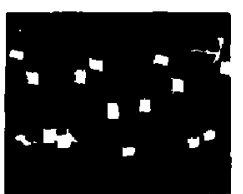

(B)

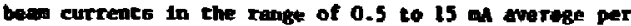
bunch.

Figure 4 shows tice-doent n waveforme for the eadulator. Figure 4:a) repreaenta a auperpasitelon of sarples of the detector output (F18. 3(b)). Thene samples are assocfated with thi ogetllation of one bunch only: the tine positioning of the wultpleker pulae alcis the datector output permitis the adjuatent of tho proper dolay ior each loop. Figure $A(b)$ is a superposition of 9.8 Hiz Rr bursts 4 th varying amplitudps; this pulat 18 applied to the porct anplifier and is timed In such a way as to arsthe at the kleker electrate 3.2 us

before the bunch. Twelve to cycles olapse durting the pulse vith. and the herin lo klchid at the polk of the last half aycle. circule.

Te now I um to a degetiption of the poter doplifier

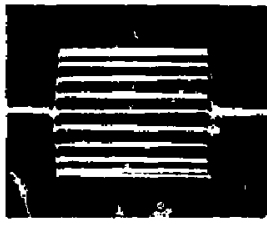

101

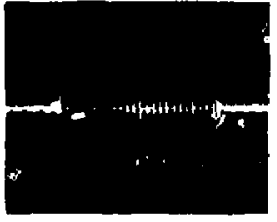

(b)

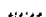

Fig. 4. (a) Hultiplexer nttput for one bunch. The modulation 16 not symchrontzed with the machsne tetrolution frequancy. (b) Modulacor output for the abowe tiput. The sartier trequetucy Is equal to the 72 ind harmole of the revolution frequency.

\section{Ponr molifier:}

The to powe wilflets are loceted in the sumal an cloce as possiblo to the dufiestion alectrodfo. To nifninize the lengeh of the nol7 conmeting ubles, and

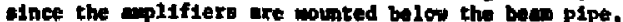

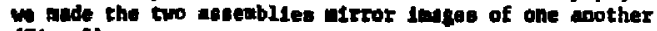
(F1, S).

Fis. 3. Detector typtcal trput-output vayeforms: (a) Input tean pules: the modulation has been eet to cimes larger so an to be visible on the phototrapl. (b) Detecter response to 37 . In kht modulation: cech step corresponds to a machine perlod. The todulat ion frequency and the revo-ution froquenty are not sppchrontzed.
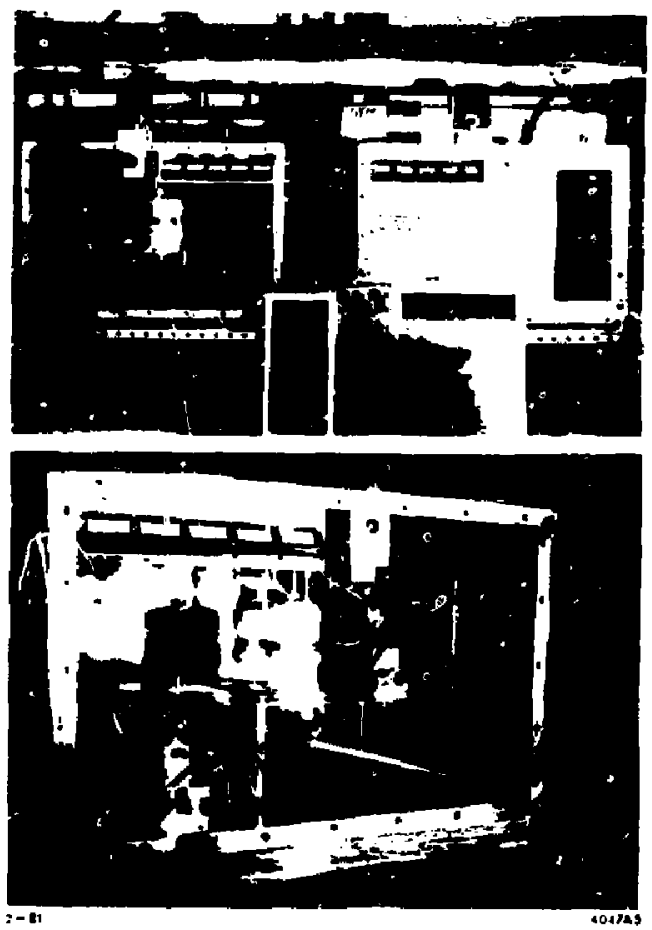

718. 5. Tro views of the powr aplifiers in the tusue1. 
Each efreult conglats of thrat push-pull stages as thow in $\mathrm{Fig}$. 6. All tank atreutte are rebistively loaded to raduce the $15 \mathrm{Q}$ and obtain the required overall banduidth of 820 ktis.

Figure 7 shows the Input and output waveformg of the power umplifler for a uareawave phase modulation. The maximute power dieeipated in the deflection alectrode 1s of the order of 300 vatte; to th1s power one must add some hisher-order mode losses and, as a result, water cooling vas deomed necessary.

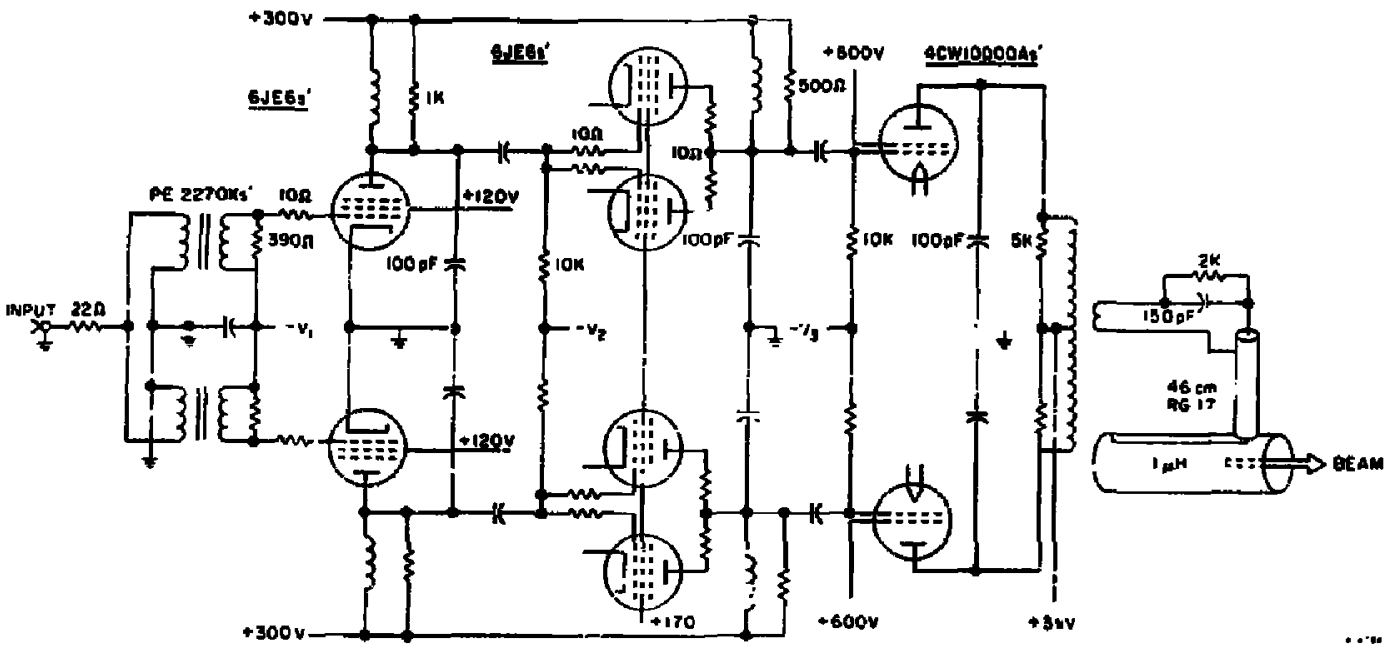

Fig. 6. Circult dlagram ot the power amplifter.

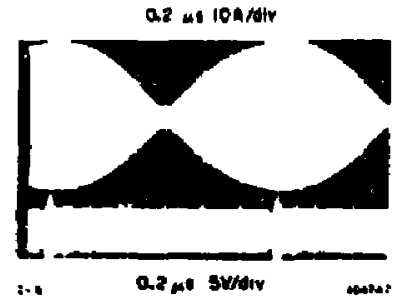

Fig. T. Hesponse of the power applitler to a square uave phase nodulation,

\section{Perfortange ind Imprevereante}

The transverse feedb-ck syscem has been used to control unstable coherent baan osclllactons when they have arland ta PEP, althouch auch ogetllatlons have caldoen been troublesome in routine operact a. With the ayates off ud vich the betoc ftee of unst -ble caherent oactllations, che nolse-driven epectrum of then motion revea1s propk ot the hortrontel ond vertieal betatron Irequenctes which are rout indy usad to madure these trequencles. Turning the foedback syatem on it high gatn obliterates the peake and produses broad notches at theoe frequencter instead.

At timen, the feedbeck wotem hat gatled to donp unacuble colierent ancillation when wo expected that it could eucesed. Then chls has happened the gystem turned out to be asturated by a otgnnt not th the Irequency of the unutabla crunsveras ouclilation, but at the (tuch lower) aynchrotron oucillation fraquancy, We plan to amellotate thts problan by rolling of the low Irequency responge of the oncillation detactore to discrimtuace agalngt the aymer ntron frequency.

Presicntly both the rertical and the hortzones powet ampliflets the tuned to the 72 nd harronic of the retrolut Jon ftequancy. In the future we plan to tune one of the wepluflexs to the 96th harmonle (13 yets), to minimize the effect of the coupling between tha vertical and the horizonenl doflection elect

\section{Acknowledsomenta}

We want to thank Jim Waver for hls deglgn if the plck-up strip I lnes and the deflecting electrodes, Leth cenovi for his anstetance with the poner supplies and the Interlocks, and Evwn Grund for helpise bringing the systere in eofuration.

\section{Deforencies}

1. S. Tazzart, ADoxt Feedback Systems; privace coamunication.

2. K. Wille, "Damping of Coherent Tranovarae Oset11ations la PETh," IEEE Trans. Hucl. ScL. 19-26. so. 3. $3281(1979)$.

3. A. Boasart, L. Burnod, J. Gareyte, B. daRaad,

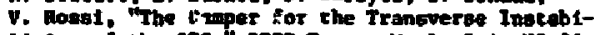
itties of the sps," IEEE Trans. "ivel. Sct. NS-26. ถูo. 3, 3294 (1979).

4. G. Carron, 8. Myera and 2. Thorndahl, "The 50 yte Trensveree Fodbuck Syatem in the CER ISR," IEEE Trans, Buel. Bot. BS-24, Mo. 3, 1813 (1977).

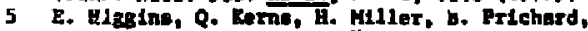
R. St Laning and G. Tool, "The Faxmllab Trangverse Instobsisty detive Dasping Syatem," IEse Irens. Nuc1. Srt. $1 \mathrm{E}-22$, No, 3, 1473 (1975).

6. J,-L. Peliegrtin "A Narmal 1zed Dotector of Beam Tranaverse ojesilationa," Nucl. Instrum. Hathods 164. 415 (1979). 